\begin{tabular}{|c|c|c|}
\hline $\begin{array}{l}\text { PUCRS } \\
\text { PUC. }\end{array}$ & $\begin{array}{l}\text { ESCOLA DE } \\
\text { HUMANIDADES }\end{array}$ & $\begin{array}{l}\text { Revista Digital do Programa de Pós-Graduação em Letras da PUCRS } \\
\text { Letrônica, Porto Alegre, v. 13, n. 1, p. 1-10, jan.-mar. } 2020 \\
\text { e-ISSN: } 1984-4301\end{array}$ \\
\hline dol http://dx & $\mathrm{org} / 10.15448 / 1984-4301.2020 .1 .35137$ & \\
\hline
\end{tabular}

\title{
A ditadura militar brasileira e os romances As meninas e As horas nuas, de Lygia Fagundes Telles
}

\author{
The brazilian military dictatorship and the novels As meninas \\ and As horas nuas, by Lygia Fagundes Telles \\ La dictadura militar brasileña y las novelas As meninas \\ y As horas nuas, de Lygia Fagundes Telles
}

\section{João Pedro Rodrigues Santos ${ }^{1}$}

orcid.org/0000-0001-7305-0090

jpsantosr@hotmail.com

Recebido em: 30 jul. 2019. Aprovado em: 24 set. 2019 Publicado em: 7 abr. 2020

\section{(c) (i)}

Artigo está licenciado sob forma de uma licença Creative Commons Atribuicãa 4.0 Internacional.
Resumo: No presente artigo apresentamos uma reflexão sobre o processo de representação de eventos históricos de censura, barbárie e tortura evidenciados nos romances As meninas e As horas nuas, da escritora brasileira Lygia Fagundes Telles. Nossa pesquisa, que teve como arcabouço teórico os pressupostos de Paul Ricoeur, aponta que a literatura e a história experimentam de forma geral, e em especial nessas obras analisadas, uma intensa simbiose. Em sintese, há história na literatura e há literatura na história. Essa troca mostra-se enriquecedora para ambas as disciplinas. Sobretudo, nos dias de hoje, torna-se cada vez mais necessário (re)lembrar os horrores praticados na ditadura militar brasileira.

Palavras-chave: Literatura. Ditadura. Tortura. História.

Abstract: In this paper we present a academic research about the process of representation of historical events of censorship, barbarism and torture evidenced in the novels As meninas and As horas nuas, by the Brazilian writer Lygia Fagundes Telles. Our research, which has as theoretical framework the assumptions of Paul Ricoeur, points out thatl iterature and history experience in general, and especially in the two fictions analyzed, an intense connection. In short, there is history in literature and there is literature in history. This exchange is profitable for both disciplines. Above all, today, it becomes increasingly necessary to remember the horrors practiced in the Brazilian Military Dictatorship.

Keywords: Literature. Dictatorial government. Torture. History.

Resumen: En este artículose presenta una reflexiónsobre elproceso derepresentaciónde eventos históricos de censura, barbarie y tortura evidenciados em As meninas e As horas nuas, de la escritora brasileña Lygia Fagundes Telles. Nuestroestudio, basado em conceptos de Paul Ricoeur,señala que la literatura y lahistoriaproban de modo general, y en particularen estas narracionesanalizadas, una simbiosis intensa. Enresumen, hayhistoriaenla literatura y hay literatura enlahistoria. Ese intercambio se revela enriquecedor a las dos asignaturas.Especialmente hoyendia, cada vez es más necesario recordar los horrores practicadosenlaDictadura Militar Brasileña.

Palabras clave: Literatura. Dictadura. Tortura. Historia.

\section{Introdução}

Neste estudo, primeiramente, pensamos que é de suma importância dar o devido lugar e mostrar a notabilidade das mulheres escritoras. A literatura produzida por mulheres, em geral, ficou à margem dos Estudos Literários. Pela sua experiência social fortemente vinculada ao espaço privado, a mulher, durante certa época, não era vista como um sujeito 
capaz de fazer arte literária, sendo considerada pela sociedade patriarcal somente como mãe e/ou dona de casa e, na literatura, como musa inspiradora e/ou personagem. Durante muito tempo, as sociedades ocidentais, em geral, não aceitavam a participação feminina no domínio público. Em vista da mentalidade vigente em relação aos papéis sociais, as mulheres passaram por muitas dificuldades no meio social e cultural para se estabelecerem como escritoras.

Muitas mulheres acabaram adotando pseudônimos masculinos para obterem a aceitação de seus textos, como foi o caso de George Sand, na França do século XIX, e das irmãs Brontë, na Inglaterra. Tal fenômeno ocorreu, também, na América Latina. De fato, a partir do século XIX, as mulheres foram, aos poucos, lutando pelo espaço da escrita, assumindo as suas autorias e as suas autoridades discursivas e literárias.

No contexto brasileiro do começo do século XX, Lygia Fagundes Telles foi uma das pioneiras ao se lançar como ficcionista. Essa escritora, nascida em São Paulo, em 1923, é dona de uma extensa produção literária, tendo publicado o seu primeiro livro em 1938 e o último, com textos inéditos, em 2007². À vista disso, a posição de Telles no cenário de nossa literatura é singular, isso porque poucos escritores conseguiram estender a sua produção literária por mais de seis décadas. Em 2005, a autora foi galardoada com o Prêmio Camões e, em 2016, foi indicada ao Prêmio Nobel de Literatura. Além disso, Telles participou de eventos importantes da história e da cultura de nosso País. Vivenciou e escreveu sobre momentos turbulentos, tais como a ditadura militar brasileira. Na verdade, Telles, corajosamente, foi uma das primeiras ficcionistas a escrever sobre as torturas e as violações dos direitos humanos enquanto elas ocorriam em plena ditadura.

Tratando-se de narrativas curtas, Telles publicou vários livros de contos ao longo do século XX e no começo do século XXI. Antes do baile verde (1970), Seminário dos ratos (1998), Invenção e memória (2000) são apenas alguns deles. Em 2018, foi publicado, pela Companhia das Letras, um livro de mais de setecentas páginas, denominado Os contos, que reúne a quase totalidade dos contos da autora.

No que tange à produção romanesca, Telles publicou as seguintes obras: Ciranda de pedra, em 1954, Verão no aquário, em 1963, As meninas, em 1973, e As horas nuas, em 1989. Nos três últimos romances citados temos um diálogo ora evidente, ora implícito, com a história de nosso País. Portanto, recorremos a Paul Ricoeur, pois o mesmo defende a aproximação entre a história e a literatura que, em sua visão, conjuntamente fazem parte da condição temporal humana.

Ricoeur, em Tempo e Narrativa (1997), problematiza a longeva (e também histórica) relação entre a história e a ficção. O autor explica que a literatura e a história encontram ambas os mesmos problemas. Por isso, pensando nas teorias do ato de leitura, os entrecruzamentos entre história e ficção são concatenados em relação a uma perspectiva do ato de leitura ampliada. Segundo o filósofo, a história e a literatura só conseguem se concretizar em suas intencionalidades tomando empréstimos uma da outra.

Desenvolvendo essa ideia, Ricoeur, mormente, defende o entrecruzamento da história com a ficção, pois ambas mantêm, e sempre mantiveram, uma relação de intensa troca. Portanto:
O que justamente faz a perenidade de certas grandes obras históricas cuja fiabilidade pro- priamente cientifica o progresso documen- tário, porém, erodiu, é o caráter exatamente apropriado de sua arte poética e retórica à sua maneira de ver o passado. A mesma obra pode, assim, ser um grande livro de história e um admirável romance. O espantoso é que esse entrelaçamento da ficção à história não enfraqueça o projeto de representância desta última, mas contribua para a sua realização (RICOEUR, 1997, p. 323).

\footnotetext{
2 Vera Maria Tietzmann Silva, em Dispersos e inéditos: estudos sobre Lygia Fagundes Telles (2009), focaliza e mapeia toda a produção literária de Telles. Silva chama a atenção para dois aspectos. Primeiramente, observa que os dois primeiros livros da autora nunca foram editados novamente, nem mesmo nenhum conto deles. Já outros livros, do inicio da carreira da ficcionista, nunca mais foram republicados enquanto obras completas, mas alguns de seus contos foram reescritos e relançados em outros livros posteriores. Conforme demonstra a pesquisadora, Telles, em entrevistas, explica que julga seus primeiros livros como sendo obras sem valor, que não merecem serem lidas. E, do mesmo modo, Telles argumenta que sua maturidade literária se deu a partir do romance Ciranda de pedra.
} 
História e ficção se enriquecem ao efetuarem trocas. A história, em certo sentido, é uma espécie de recriação e representação de eventos que, evidentemente, aconteceram. Ricoeur postula que podemos ler um livro de história como se fosse um romance, fazendo, então, um pacto entre a voz narrativa e o leitor implicado. Enquanto leitores, em função desse pacto, às vezes, abaixamos a guarda. E deixamos nossa possivel desconfiança esmorecer em relação à narrativa do historiador. Acreditamos que tudo o que está escrito na narrativa histórica é verdadeiro e corresponde exatamente ao que aconteceu.

Para o teórico francês, quando fizemos esse pacto, chegamos a conceder ao historiador o direito de conhecer as almas das personagens históricas. Em função dessa suspensão involuntária da descrença dos leitores em relação às narrativas históricas, os historiadores de antigamente não hesitavam em atribuir às figuras históricas discursos inventados que os documentos e registros não legitimavam, mas tornavam possiveis. Todavia, "Os historiadores modernos já não se permitem essas incursões fantasistas, no sentido próprio da palavra" (RICOEUR, 1997, p. 323).

É inegável a influência da história na ficção e vice-versa. Mesmo os historiadores modernos, que já não se concedem a liberdade de recuperar frases e falas de personagens históricas, não deixam de recorrer, de forma menos ou mais explícita, ao gênero romanesco. Um exemplo dessa relação é o livro best-seller 1808 - Como uma rainha louca, um príncipe medroso e uma corte corrupta enganaram Napoleão e mudaram a história de Portugal e do Brasil, de Laurentino Gomes (2007), que flerta diretamente com a ficção e utiliza recursos textuais e retóricos próprios da literatura.

Ricoeur contemporiza dizendo que "O historiador não se proíbe, então, 'pintar' uma situação, 'restituir' uma cadeia de pensamentos e dar a esta a 'vivacidade' de um discurso interior" (RICOEUR, 1997, p. 323). Como sabemos, a ficção também se utiliza de fatos históricos para pintar os seus enredos e ambientar as suas narrativas. De acordo com os pressupostos do autor francês, a literatura tem um papel importante em registrar e individualizar situações de horror, como no caso do holocausto na segunda Guerra Mundial:

\begin{abstract}
Ao assim se fundir com a história, a ficção reduz está última à sua origem comum na epopeia. Mais exatamente, o que a epopeia fizera na dimensão do admirável, a lenda das vítimas o faz no horrivel. Essa epopeia, por assim dizer negativa, preserva a memória do sofrimento, nas escalas dos povos, como a epopeia e a história em seus primórdios haviam transformado a glória efêmera dos heróis em fama duradoura. Em ambos os casos, a ficção se põe a serviço do inesquecivel. Ela permite que a historiografia se iguale à memória, pois uma historiografia pode ser sem memória, quando só a curiosidade a anima (RICOEUR, 1997, p. 327).
\end{abstract}

Em ambos os casos, seja na dimensão do nefasto ou do louvável, a ficção se coloca a serviço de aplacar o esquecimento. Desde muito tempo, literatura e história se retroalimentam. Já nas epopeias, como, por exemplo, Os Lusiadas, vemos mescladas história e literatura. Contudo, enquanto obras como a de Luís Vaz de Camões retratam o heroísmo, romances que falam sobre o holocausto, sobre as guerras, sobre as ditaduras, mostram o horror e o (in)dizivel.

Logo, seja para grandezas ou para catástrofes, a ficção serve como forma de mitigar o esquecimento. A literatura preserva memórias coletivas e representações de eventos históricos que não podem ser esquecidos.

Ricoeur assinala que "talvez haja crimes que não se devam esquecer, vitimas cujo sofrimento peça menos vingança do que narrativa. Só a vontade de não esquecer pode fazer com que esses crimes não voltem nunca mais" (RICOEUR, 1997, p. 327). Dessa forma, ao narrar crimes bárbaros, como os da nossa ditadura militar, almejamos que eles não se repitam, mesmo que narrados de forma ficcional como nos romances que falaremos aqui.

Então, nestes entrelaçamentos e nestas trocas, conseguimos conciliar a representação do passado histórico com a fruição ficcional:

Para concluir, o entrecruzamento entre a história e a ficção na refiguração do tempo se baseia, em última análise, nessa sobreposição recíproca, quando o momento quase histórico da ficção troca de lugar com o momento quase fictício da história. Desse entrecruzamento, 
dessa sobreposição reciproca, dessa troca de lugares, procede o que se convencionou chamar de tempo humano, em que se conjuga a representância do passado pela história e as variações imaginativas da ficção sobre o pano de fundo das aporias da fenomenologia do tempo (RICOEUR, 1997, p. 332).

Tendo em vista o que expomos até aqui, vamos falar agora sobre como se dá esta combinação entre história e literatura nos dois últimos romances de Telles.

O historiador e jornalista Elio Gaspari, em seus livros A ditadura envergonhada (2002), A ditadura escancarada (2002), A ditadura derrotada (2003), A ditadura encurralada (2004) e A ditadura acabada (2016), basicamente, desvela os vinte e um anos (1964 - 1985) em que os militares, com apoio de uma parte da população civil, comandaram o Brasil. O regime ditatorial foi instaurado em $1 .^{\circ} \mathrm{de}$ abril de 1964 e durou até 15 de março de 1985, sob o comando de sucessivos governos militares. De caráter extremamente autoritário, este governo teve início com o golpe militar que derrubou o governo de João Goulart, democraticamente eleito. O regime acabou quando José Sarney assumiu a presidência, o que deu início ao periodo conhecido como Nova República. Assim, aos poucos, o Brasil foi retomando a sua democracia.

Apesar das promessas iniciais de uma "intervenção breve" para reestabelecer a ordem, a ditadura militar brasileira durou vinte e um anos. O regime colocou em prática vários Atos Institucionais, culminando com o Ato Institucional Número Cinco (Al-5) de 1968, que vigorou por dez anos. A Constituição de 1946 foi anulada e, ao mesmo tempo, o Congresso Nacional foi dissolvido. Liberdades civis foram suprimidas e foi criado um código de processo penal militar que permitia ao Exército Brasileiro e a Polícia Militar prender, encarcerar e torturar pessoas que faziam oposição ou, simplesmente, eram consideradas suspeitas, além de impossibilitar qualquer revisão judicial.

Embora nosso artigo focalize os dois últimos romances de Lygia Fagundes Telles, pensamos ser pertinente citar uma passagem de Verão no aquário. Nesse livro, publicado pela primeira vez em 1963, há um trecho que preambula o golpe militar materializado em 1964, pouco tempo depois da publicação do romance:

- Raíza, você está parecendo o André, ele já me falou nessa história de sair de espada em punho, salvar não sei o quê, provavelmente o mundo... Mas se nem aqui, nesta pátria em perigo, hein? Desde que nasci ela está em perigo, e então? Fazer o quê? Tem lido os jornais? Já está engrossando por aí uma revolução para derrubar o presidente, coisa de militar, compreende? Me dá depressa a fórmula, impedir uma outra ditadura, posso escrever às chamadas cúpulas políticas meus bilhetinhos de protesto, me enfiar numa armadura ir à luta - é isso que você espera de mim?

- Somos capazes de ódio, mas não somos capazes de indignação, o que é diferente. Deus vai nos vomitar.

- Não seja pretensiosa, estaremos em outros vômitos, não nesse, compreende?

- Marfa, escuta - eu comecei. - Não se trata de salvar o mundo...

- Mas se nem neste nosso miserável metro quadrado a gente pode interferir, compreende? (TELLES, 2010, p. 74-75).

Já no terceiro romance de Telles, As meninas, temos representada a "ditadura escancarada", como cunhou Gaspari. Segundo o autor, em A ditadura escancarada (2002), a partir de 1968, a ditadura foi ostensiva e perdeu o pudor, o estado de exceção firmou-se. A "ditadura envergonhada" foi substituida por um regime que promoveu perseguições, barbáries, medos e violações. Todo material que fizesse oposição, criticasse ou tivesse qualquer mínimo teor oposicionista ao então governo ditatorial era censurado e proibido. Muitos artistas, escritores, intelectuais, professores, politicos etc., tiveram que deixar o País ou foram torturados e/ou mortos. Esses foram os "anos de chumbo". Nas palavras de Gaspari:

Escancarada, a ditadura firmou-se. A tortura foi seu instrumento extremo de coerção e o extermínio, o último recurso da repressão política que o Ato Institucional $n^{\circ} 5$ libertou das amarras da legalidade. A ditadura envergonhada foi substituída por um regime a um só tempo anárquico nos quartéis e violento nas prisões. Foram os Anos de Chumbo. [...] Foi o mais duro periodo da mais duradoura das ditaduras nacionais. Ao mesmo tempo, foi a época das alegrias da Copa do Mundo de 1970, do aparecimento da TV em cores, das inéditas taxas de crescimento econômico e de um regime de pleno emprego. Foi o 
Milagre Brasileiro. O Milagre Brasileiro e os Anos de Chumbo foram simultâneos. Ambos reais, coexistiram negando-se. Passados mais de trinta anos, continuam-se negando. Quem acha que houve um, não acredita (ou não gosta deadmitir) que houve outro. [...] Os oficiais-generais que ordenaram, estimularam e defenderam a tortura levaram as Forças Armadas Brasileiras ao maior desastre de sua história. A tortura tornou-se matéria de ensino e prática rotineira dentro da máquina militar de repressão política da ditadura por conta de uma antiga associação de dois conceitos. O primeiro, genérico, relaciona-se com a concepção absolutista da segurança da sociedade. Vindo da Roma Antiga ("A segurança pública é a lei suprema"), ele desemboca nos porões: "Contra a Pátria, não há direitos", informava uma placa pendurada dos elevadores da polícia paulista. Sua lógica é elementar: o país está acima de tudo, portanto, tudo vale contra aqueles que o ameaçam. O segundo conceito associa-se à funcionalidade do suplício. A retórica dos vencedores sugere uma equação simples: havendo "terroristas", os militarem entram em cena, o pau canta, os presos falam, e o terrorismo acaba (GASPARI, 2002, p. 15-17).

Indo ao encontro desse momento histórico, As meninas, publicado pela primeira vez em 1973. no auge dos "anos de chumbo", até hoje envolve um certo mistério relativo ao fato de ter passado pelos censores da ditadura.

Em seu livro memorialístico, Conspiração de nuvens (2007), Telles conta que estava escrevendo o romance quando chegou em suas mãos um texto descrevendo uma sessão de torturas, ocorrida nos porões do regime militar. Seu marido, Paulo Emílio Salles Gomes, intelectual e professor da Universidade de São Paulo (USP), a incentivou a aproveitar o conteúdo do texto no seu livro, e ela o fez através da voz da personagem Lia. Segundo a autora, a censura aprovou o romance porque o censor achou o livro chato e não leu além das primeiras páginas, por isso, não chegou nos trechos em que eram descritos os flagelos. A escritora nos explica como as coisas aconteceram:

Um jornalista pediu-me detalhes, E então? Tinha algum livro ameaçado de proibição? Contei-lhe que publiquei um romance, As meninas, no qual uma das personagens, exatamente uma jovem subversiva, lê um panfleto que Paulo Emilio recebeu pelo correio. Era o relato desesperado de um preso político torturado provavelmente até a morte. A solução que encontrei foi reproduzir o panfleto que a minha personagem subversiva vai lendo para uma freira. [...] Dobrei a cópia da página do meu livro e guardei-a na bolsa. Então esse romance saiu em 1973, acrescentei. O jovem ficou me olhando meio perplexo, E ainda não foi censurado? Perguntou e contei-lhe o que Paulo Emilio tinha ouvido, o censor chegou até a página 72 e não foi adiante porque achou o livro chato (TELLES, 2007, p. 64-65).

A narrativa de As meninas é ambientada na cidade de São Paulo. No pensionato de freiras Nossa Senhora de Fátima vivem três jovens estudantes: Ana Clara, Lia e Lorena. Essas meninas estão descobrindo os enigmas do mundo e tentando encontrar sentido para as suas existências. A história nos mostra três personagens vivendo em um país convulsionado e com inúmeros problemas sociais. Acima de tudo, o texto de Telles descortina uma nação amedrontada por um regime ditatorial violento. É memorável a amizade entre Ana Clara, Lia e Lorena, que, tão díspares, amavam-se tanto.

A ficcionista optou, talvez como uma estratégia para o romance não ser visado pelos censores, dara um livro tão incomum um título tão singelo. No final do romance é mencionada, por uma personagem, a obra infanto-juvenil, outrora muito popular e lida por diversas gerações, As meninas exemplares (1971), da Condessa de Ségur, como uma espécie de ironia. Isso porque o livro de Séguré, é pleno de lições morais, ao contrário de As meninas.

Segundo a pesquisadora Vera Maria Tietzmann Silva, em seu livro Dispersos e inéditos: estudos sobre Lygia Fagundes Telles (2009):

O terceiro romance de Lygia Fagundes Telles, As
meninas, constitui um marco na obra da autora,
sobretudo na experimentação que ela efetuou
no uso do foco narrativo. Trata-se de uma sinfonia
de múltiplas vozes, que exige um leitor atento
e competente. Em consonância com a época
retratada, Lygia optou pelo foco múltiplo, su-
gerindo, assim, indiretamente, a fragmentação,
o caos e a incomunicabilidade desse tempo de
sombras da história nacional (SILVA, 2009, p.113).

Seguindo um curto tempo cronológico, apenas dois dias, a narrativa mergulha na vida interior de Lorena Vaz Leme, Lia de Mello Schultz e Ana Clara Conceição. O foco narrativo oscila livremente entre as três, deixando um possivel "leitor desatento", quem sabe, um pouco confuso. Contudo, vamos nos habituando a multiplicidade de vozes e 
começamos a saber, quando estamos lendo, quem está falando, pois cada uma das meninas têm uma forma diferente de se expressar. A delicada Lorena, descendente de bandeirantes, ama um homem casado, mas permanece virgem. Lia é filha de uma baiana com um alemão, milita na luta contra a ditadura e contra o sistema capitalista. Ana Clara, que é órfã, oscila entre o desejo de ascensão social e o paraíso artificial das drogas.

O namorado de Lia está preso, enquanto isso ela se reúne com grupos clandestinos que desejam libertar os presos políticos e derrubar a ditadura. Em determinado momento da narrativa, a personagem nos deixa conhecer alguns de seus pensamentos sobre a situação em que está inserida:

Acendo um cigarro. Que me importa dormir no meio dos bêbados, das putas, o cigarro aceso no meu peito, dói sim, mas se soubesse que você está livre, dormindo na estrada ou debaixo da ponte. Mas livre. Não sei aguentar sofrimento dos outros, entende? O seu sofrimento, Miguel. O meu aguentaria bem, sou dura. Mas se penso em você fico uma droga, quero chorar. Morrer. E estamos morrendo. Dessa ou de outra maneira não estamos morrendo? Nunca o povo esteve tão longe de nós, não quer nem saber. E se souber ainda fica com raiva, o povo tem medo, ah! como o povo tem medo. A burguesia aí toda esplendorosa. Nunca os ricos foram tão ricos, podem fazer as casas com as maçanetas de ouro, não só os talheres, mas as maçanetas das portas. As torneiras dos banheiros. Tudo de puro ouro como o gangster grego ensinou na sua ilha. Intactos. Assistindo da janela e achando graça. Resta a massa dos delinquentes urbanos. Dos neuróticos urbanos. E a meia dúzia de intelectuais. Os simpáticos simpatizantes. Não sei explicar mas tenho mais nojo de intelectual do que de tira. Esse ao menos não usa máscara, ô Miguel! Precisava tanto de você hoje, esta vontade de chorar, lá sei. Mas não choro (TELLES, 2009, p. 19-20).

Lia quer asilo político em outro país para ela e para o seu namorado. Nas últimas páginas do romance, o namorado de Lia finalmente é libertado e os dois vão morar na Argélia. O ano em que se passa a narrativa é 1969, indicado sutilmente pela referência feita ao sequestro do embaixador norte-americano Charles Elbrick. O referido sequestro que, de fato ocorreu na época, resultou na libertação de cerca de quinze presos politicos brasileiros. No romance, Telles amalgama ficção e realidade, pois é possivel entender que o namorado de Lia foi um dos presos libertados.
Os terrores da ditadura são abordados no romance, às vezes de forma velada, às vezes mais explicitamente. $\mathrm{O}$ trecho mais emblemático do livro é quando Lia resolveu ler, para uma das freiras que administra o pensionato, o depoimento que circulava clandestinamente no País. Portanto, transcrevemos aqui essa parte do romance:

- Quero que ouça o trecho do depoimento de um botânico perante a Justiça, ele ousou distribuir panfletos numa fábrica. Foi preso e levado à caserna policial, ouça aqui o que ele diz, não vou ler tudo:

"Ali interrogaram-me durante vinte e cinco horas enquanto gritavam, Traidor da pátria, traidor! Nada me foi dado para comer ou beber durante esse tempo. Carregaram-me em seguida para a chamada capela: a câmara de torturas. Iniciou-se ali um cerimonial frequentemente repetido e que durava de três a seis horas cada sessão. Primeiro me perguntaram se eu pertencia a algum grupo político. Neguei. Enrolaram então alguns fios em redor dos meus dedos, iniciando-se a tortura elétrica: deram-me choques inicialmente fracos que foram se tornando cada vez mais fortes. Depois, obrigaram-me a tirar a roupa, fiquei nu e desprotegido. Primeiro me bateram com as mãos e em seguida com cassetetes, principalmente nas mãos. Molharam-me todo, para que os choques elétricos tivessem mais efeito. Pensei que fosse então morrer. Mas resisti e resisti também às surras que me abriram um talho fundo em meu cotovelo. Na ferida o sargento Simões e o cabo Passos enfiaram um fio. Obrigaram-me então a aplicar choques em mim mesmo e em meus amigos. Para que eu não gritasse enfiaram um sapato dentro da minha boca. Outras vezes, panos fétidos. Após algumas horas, a cerimônia atingiu seu ápice. Penduraram-me no pau-de-arara: amarraram minhas mãos diante dos joelhos, atrás dos quais enfiaram uma vara, cujas pontas eram colocadas em mesas. Fiquei pairando no ar. Enfiaram-me então um fio no reto e fixaram outros fios na boca, nas orelhas e mãos. Nos dias seguintes o processo se repetiu com maior duração e violência. Os tapas que me davam eram tão fortes que julguei que tivessem me rompido os tímpanos, mal ouvia. Meus punhos estavam ralados devido às algemas, minhas mãos e partes genitais completamente enegrecidas devido às queimaduras elétricas. $\mathrm{E}$ etecetera, etecetera."

- Dobro a folha. Madre Alix me encara. Os olhos cinzentos têm uma expressão afável.

- Conheço esse bilhete, filha. Esse moço chama-se Bernardo. Tenho estado muito com a mãe dele, fomos juntas falar com o Cardeal (TELLES, 2009, p. 148-149).

Ao ler o depoimento, o que mais choca é saber que isso não foi somente ficção. Essas e muitas 
outras práticas de torturas, mortificações e flagelos realmente aconteceram. Os militares brasileiros eram "bons" em torturar, como atesta Leandro Karnal:

O livro Brasil nunca mais, cuja introdução foi assinada pelo falecido Cardeal D. Paulo Evaristo Arns, descreve as torturas no período militar instaurado em 1964. No livro se faz uma pergunta pertinente: por que gente do Cone Sul, de outras ditaduras instauradas na região, vinham ao Brasil apreender mais sobre técnicas de tortura? Por que naquela época chegou a haver aula de tortura no Rio de Janeiro. A resposta que se pode dar tem a ver com a nossa tradição escravista. Uma tradição mantida no modo de agir da polícia, no nosso modelo policial, no qual a polícia cientíica anda lado a lado com a polícia do "pau de arara" (KARNAL, 2017, p. 22).

Agora, falaremos sobre o romance As horas nuas, publicado, em 1989, quando o País estava empolgado com a retomada da democracia. O romance As horas nuas conta a história de Rosa Ambrósio, atriz de meia-idade que começa a se confrontar com as suas lembranças e almeja acertar as contas com o passado. Essa personagem, antigamente, atuou em muitas peças de teatro e fez sucesso. No entanto, quando o romance começa, ela encontra-se esquecida e sozinha. Assim, passa os dias em seu apartamento, bebendo uisque e tentando entender tudo o que aconteceu em sua vida. A única companhia de Rosa é seu gato, Rahul. A narrativa é contada, então, a partir de dois focos: Rosa e Rahul, os quais alternam os capítulos do romance. Rahul é um gato antropomorfizado, inclusive, ele guarda lembranças de possiveis vidas passadas que viveu.

Rosa Ambrósio pensa em escrever uma autobiografia que se chamará "As horas nuas". Em vista disso, ela começa a visitar as suas memórias, gravando narrações de fatos passados de sua vida em um gravador de áudio. Nessas lembranças, são invocados seus três grandes amores: Miguel, Gregório e Diogo. Na juventude, Rosa apaixonou-se por seu primo, Miguel, mas ele acabou morrendo por causa de uma overdose de drogas. Gregório também abandonou a atriz através da morte, ele era professor universitário e foi perseguido, exilado e torturado durante o período da ditadura militar brasileira. Após ser torturado, Gregório ficou melancólico, com muitas sequelas e acabou por se suicidar. Já Diogo, está vivo, mas não quer mais a companhia de Rosa. Além disso, a protagonista tem problemas de relacionamento com sua filha, não gosta do mundo em que vive e sente-se deslocada de tudo e de todos. Restam apenas o tempo que passou e as suas lembranças. Então, pouco a pouco, Rosa nos desnuda as suas memórias ao revisitar o seu passado. Através das rememorações da personagem nos confrontamos com as cicatrizes do período histórico da ditadura.

Nesse sentido, temos representações históricas na narrativa que recuperam a ditadura militar no Brasil ou, mais especificamente, as vitimas e os traumas da ditadura militar brasileira. Gregório, o marido de Rosa, como já mencionamos, era professor universitário. Em função de ser contrário ao regime militar, ele foi perseguido, preso e torturado pelos militares, depois, terminou por se exilar algum tempo na França. Quando Gregório volta, já não é mais o mesmo homem. As cicatrizes físicas e psicológicas, os traumas das torturas e todas as pressões fazem com que ele se suicide.

Desde o começo do romance, observamos as inscrições históricas que permeiam o texto de Telles. Rosa sente remorso pela morte de Gregório, pois nunca conseguiu entender direito o que aconteceu com ele. Ele não conseguiu narrar para ela o que vivenciou. Ela só sabe que ele sofreu e mudou. A personagem nos explica:

Tudo somado, um longo plano de evasão fragmentado em fugas miúdas. Diárias. Que foram se multiplicado, não leio mais jornais, desliguei a TV com suas desgraças em primeiríssima mão, crimes humanos e desumanos, catástrofes e calamidades naturais e provocadas. Ah! um cansaço. Por que ficar sabendo tudo se não posso fazer nada? Posso dar agua aos flagelados ressequidos? dar uma toalha de rosto aos inundados? Hein?!... As tragédias se enredando sem trégua. Não tenho culpa se tomei horror pelo horror conformado. A miséria paciente. Minha mulher, doutor, mais o meu filho com barraco e tudo. Nem o cachorro salvou, sumiu no meio da água, do barro... A Dinamarca envia caixotes de vacinas, o Papa pede a Deus em português. Lá do alto do palanque os políticos filhos da puta exigem providências. Meus irmãos, meus irmãozinhos! E os irmãozinhos continuam morrendo como moscas. Ah querido Gregório, perdão, mas não suporto mais tanta miséria, merda! Fui 
batizada, catequizada, conscientizada e tudo isso para ter a certeza de que não sou Deus e mesmo que fosse. Estou ciente, e daí? Não, não adianta se revoltar, Gregório se revoltou, partiu para o confronto e acabou cassado, dependurado, torturado. Sua linda cabeça pensante levando choque, porrada. Atingido no que tinha de mais precioso. Ferido para sempre (TELLES, 2010, p. 14-15).

Sabemos do que ocorreu com Gregório a partir da ótica de Rosa e Rahul. Inclusive, é Rahul a única testemunha do suicídio do marido da atriz. A passagem do romance que mostra esse suicídio descrito pelo prisma do gato é um dos pontos altos do enredo. A personagem de Gregório é uma denúncia do trauma, do que fica depois do conflito, das feridas que nunca cicatrizam, da dor que nunca cessa. A atriz enfatiza durante todo o romance que o maior dano causado a Gregório foi em sua cabeça, ou seja, o dano psicológico:

O pobrezinho. Nunca mais foi o mesmo. Saiu da prisão diferente, mais fechado, mais calado, ô! meu Pai, mas o que fizeram com ele? Atingido no que tinha de mais precioso, a cabeça, sentia dores. A mão tremendo tanto, disfarçava quando acendia o cachimbo, o que fizeram?! Perguntou e acendeu outro cigarro, mas ficou olhando a brasa. Escrevia, amarfanhava e jogava no cesto, Por que você escreve e destrói em seguida? Ele sacudiu a cabeça, só rabiscos, não era nada. Nada. Diogo estranhou, Você que é tão curiosa nunca teve a curiosidade de fuxicar no cesto? (TELLES, 2010, p. 40).

Parece que Gregório tenta de algum modo expressar o seu sofrimento escrevendo, mas não consegue e acaba colocando no lixo tudo o que escreve, o sofrimento dele carece de palavras para ser dito. Em certo momento, Rosa relembra como era difícil conviver com Gregório depois que o mesmo saiu da prisão. Ele tornou-se um homem taciturno e solitário. O que o marido de Rosa presenciou e sofreu talvez seja inominável e indizivel:

É dificil, um homem-nó. E só. Por acaso Ananta sabia o que era conviver com um homem atado por dentro num nó cego? Cassado e torturado pela ditadura militar, Ah, voltou mais irreconhecivel. Gaguejava de repente, ele que falava tão bem nas suas aulas, conferências. Trôpego, eu ouvia às vezes seus passos e tinha vontade de chorar, mas o que aconteceu, meu pai! Conta pelo amor de Deus, o que fizeram com você?... Então ele disfarçava, eu disfarçava, nós disfarçávamos, esse verbo, passado-não-sei-mais. O comportamento de
Cordélia contribuindo para piorar a doença, é claro. E o meu comportamento com Diogo, merda! (TELLES, 2010, p. 139).

Com efeito, notamos que Gregório não consegue expressar o que viveu. O medo e o trauma dessa personagem são doloridos, ele não vê mais significado em sua existência. Talvez o padecimento e o trauma sejam, em certas instâncias, indiziveis. Podemos apenas representálos através de narrativas ficcionais e históricas para tentar evitar a sua repetição. Olhando por esse ângulo, pensamos que o sofrimento de Gregório é somente seu, ele não consegue descrever e narrar o que viveu. Quem nos oferece significados para a experiência vivida por Gregório é Rosa. Por conseguinte, o romance de Telles, como um todo, torna visivel a memória das torturas efetivadas durante a ditadura militar brasileira.

Observa-se, no excerto seguinte, a percepção de Rosa sobre essa impossibilidade de Gregório dizer o trauma:

\begin{abstract}
Sei que voltou da prisão um outro homem, não é assim que se diz? O passo tropeçante e de repente, o terror no olhar, o terror que disfarçava, mas porque tinha que disfarçar tanto assim? Por que não se abria comigo, com a filha, com os amigos, por que evitava todo mundo, ainda o medo? O que fizeram com ele naquela prisão repelente? Eu ficava me perguntando e até hoje. Atingido no que tinha de mais precioso, a cabeça, ah!, chega, já disse tudo isso e estou repetindo, chega (TELLES, 2010, p. 200-201).
\end{abstract}

Não conseguimos entender o sofrimento alheio por completo. O que podemos é tentar dar memória para a dor, aplacando o esquecimento. A atriz nos revela uma metáfora que Gregório usava para falar sobre os exilados políticos do Brasil. Ele contava um caso de um rio-assassino que rejeitava uma certa espécie de peixe, pois não queria esse peixe em suas águas. E o peixe tinha que se abraçar desesperadamente na água que o expulsava e o repelia, tinha que se segurar e tentar seguir em frente para sobreviver em uma água que queria a sua destruição:

E me lembro agora de um caso tão estranho que me contou, o caso do rio-assassino que rejeitava uma certa espécie de peixe, não queria esse peixe em suas águas. E o pobre peixe se abraçando desesperadamente à água 
que o expulsava, que o cuspia para a terra. Os peixes expatriados. Que precisavam lutar com mais empenho do que os outros para a sobrevivência humilhante nas margens turvas, lá no fundo turvo do rio inimigo. Os peixes exilados. Na manhã em que ele foi embora debaixo daquela organza tolamente disfarçante pensei de repente nessa história terrivel que um amigo the contou quando esteve exilado na França e dai comecei a chorar aos gritos porque vi nele o peixe cinza descamado dentro da rede lilás (TELLES, 2010, p. 186-187).

Brasil: ame-o ou deixe-o. Era esse o lema da ditadura militar. Por isso, Gregório, metaforicamente, era o peixe que o rio expulsou. E para tentar sobreviver, depois de todo o horror vivido, tinha que lutar duas vezes mais do que os outros, necessitava lutar por uma sobrevivência humilhante à margem da vida. A literatura, evidentemente, é dotada da possibilidade de carregar a história por meio das metáforas e das representações.

Comparando os dois romances aqui analisados, entendemos que cada um deles estabelece uma relação diferente com a história: Asmeninas foi publicado enquanto os eventos históricos ocorriam, já As horas nuas tem um pequeno distanciamento temporal. Isso é, em As meninas temos uma crônica dos "anos de chumbo". Em As horas nuas temos as memórias e os traumas que o regime deixou.

O êxito desses dois romances estudados provêm das impressões de profunda veracidade e poder de convencimento que eles oferecem. Eles atuam sobre nós, leitores, através de todos os ingredientes que as obras de ficção trazem: estratégias narrativas qualificadas, temas de interesse humano tratados em suas complexidades, existência de situações paradoxais apontadas, mas sem resolução por sua própria natureza, capacidade de ampliação dos horizontes dos leitores e conhecimento da história.

\section{Considerações finais}

Após analisarmos os romances de Telles ao longo deste artigo, reiteramos a perspectiva de Paul Ricoeur (1997) sobre a relação entre literatura e história. Ficção e história articulam-se estabelecendo trocas mútuas, pois existe ficção na história, do mesmo modo que existe história na ficção. Sobretudo, pensamos que a história e a literatura, entre tantas coisas, servem para registrar a memória do horror e tentam evitar que ele se repita.

Ademais, com o nosso estudo, buscamos evidenciar a coragem de Lygia Fagundes Telles ao descrever no seu romance uma cena de tortura enquanto as torturas realmente aconteciam, em uma época de censura feroz, em que a mera referência à oposição era proibida. Possivelmente, As meninas passou pela censura porque o livro era dificil demais para o censor, e ele não conseguiu seguir adiante na leitura, parando antes do depoimento. O livro, lançado no final de 1973, foi o romance brasileiro mais vendido durante o ano de 1974. Livro que falava da realidade imediata, e que é tão atual hoje, tantos anos depois.

Também, não menos importante é o romance As horas nuas, publicado já na época da Nova República. O romance As horas nuas aponta o início do período democrático no Brasil, após anos de ditadura militar. Ao tentar escrever o seu livro de memórias, a protagonista faz o registro da experiência vivida por Gregório, o seu esposo cassado e torturado durante o regime. Ao falar do marido, morto em decorrência das sequelas da tortura, Rosa encontra uma forma de dar um testemunho, pois não se esquece de lembrar ao leitor os efeitos devastadores de quaisquer regimes autoritários.

Pensando no contexto da América Latina, podemos aproximar Telles e seus romances de outras escritoras que também abordaram as ditaduras de seus respectivos países em suas obras. Durante o século XX, mais da metade das nações latino-americanas foram tomadas por governos ditatoriais, em muitos casos com o apoio norte-americano que justificava evitar governos comunistas. Argentina, Bolivia, Chile, Peru e República Dominicana foram alguns desses países.

No caso do Chile, entre outras obras, temos A casa dos espiritos (2010), de Isabel Allende, publicada originalmente em 1982, também enquanto o Chile ainda vivia na ditadura comandada por Augusto Pinochet. Nesse romance temos a saga da familia Trueba. A narrativa acompanha três de suas gerações por 
meio das personagens femininas que ocupam os lugares de mãe, de filha e de neta, percorrendo quase todo o século XX.

De maneira semelhante, no caso da República Dominicana, destaca-se o romance No tempo das borboletas (2001), que foi escrito por Julia Alvarez, tendo sido publicado, pela primeira vez, em 1994. O romance conta a história das irmãs Mirabal e da ditadura comandada por Rafael Leónidas Trujillo, na República Dominicana. Tal como em As meninas, o foco narrativo também oscila dando voz as quatro irmãs para que cada uma conte uma parte da narrativa. As irmãs Mirabal realmente existiram, portanto, Alvarez também intersecciona literatura e história, reconstruindo ficcionalmente a trajetória das irmãs.

Dessa forma, os romances de Allende e Alvarez dialogam com os romances de Telles aqui focalizados, pois foram escritos por mulheres e, em suas narrativas, temos mulheres protagonistas contando as suas histórias pessoais e de seus paises, entrecruzando história e ficção. Assim sendo, seria pertinente um estudo sob essa ótica, estabelecendo pontos de contato entre as obras referidas.

\section{Referências}

ALLENDE, Isabel. A casa dos espiritos. Tradução de Carlos Martins Pereira. Rio de Janeiro: Bertrand Brasil, 2010.

ALVAREZ, Julia. No tempo das borboletas. Tradução de Léa Viveiros de Castro. Rio de Janeiro: Rocco, 2001.

GASPARI, Elio. A ditadura acabada. Rio de Janeiro: Intrinseca, 2016

GASPARI,Elio. A ditadura derrotada. São Paulo: Companhia das Letras, 2003.

GASPARI, Elio. A ditadura encurralada. São Paulo: Companhias das Letras, 2004.

GASPARI, Elio. A ditadura envergonhada. São Paulo: Companhia das Letras, 2002.

GASPARI, Elio. A ditadura escancarada. São Paulo: Companhia das Letras, 2002.

GOMES, José Laurentino. 1808: Como uma rainha louca, um príncipe medroso e uma corte corrupta enganaram Napoleão e mudaram a história de Portugal e Brasil. São Paulo: Planeta do Brasil, 2007. https://doi.org/10.9771/2317-1219rf.v12i12.3004
KARNAL, Leandro. Todos contra todos: O ódio nosso de cada dia. Rio de Janeiro: Leya, 2017.

RICOEUR, Paul. Tempo e Narrativa. Tradução de Maria da Penha Villela-Petit. Campinas: Papirus, 1997. Tomo III.

SÉGUR, Condessa de. As meninas exemplares. Rio de Janeiro: Ediouro, 1971,

SILVA, Vera Maria Tietzmann. Dispersos e inéditos: Estudos sobre Lygia Fagundes Telles. Goiania: Cânone editorial, 2009 .

TELLES, Lygia Fagundes. As horas nuas. São Paulo: Companhia das Letras, 2010.

TELLES, Lygia Fagundes. As meninas. São Paulo: Companhia das Letras, 2009

TELLES, Lygia Fagundes. Conspiração de nuvens. Rio de Janeiro: Rocco, 2007.

TELLES, Lygia Fagundes. Verão no aquário. São Paulo: Companhia das Letras, 2010

\section{Endereço para correspondência}

João Pedro Rodrigues Santos

Rua Visconde de Paranaguá, 102

Centro, 96203-900

Rio Grande, RS, Brasil

\section{João Pedro Rodrigues Santos}

Doutorando em Letras - História da Literatura na Universidade Federal do Rio Grande (FURG). Bolsista CAPES. Pesquisa as relações entre literatura, história e memória. 